ASTHMA

\title{
Airway hyperresponsiveness and bronchial mucosal inflammation in T cell peptide-induced asthmatic reactions in atopic subjects
}

\author{
F Runa Ali, A Barry Kay, Mark Larché
}

Thorax 2007;62:750-757. doi: 10.1136/thx.2006.072041

See end of article for authors' affiliations

Correspondence to: Professor A B Kay, Leukocyte Biology Section, Sir Alexander Fleming Building, South Kensington Campus, Imperial College, London SW7 2AZ, UK; a.b.kay@ imperial.ac.uk

Received 21 September 2006 Accepted 6 February 2007 Published Online First 27 March 2007

\begin{abstract}
Background: Subjects with allergic asthma develop isolated late asthmatic reactions after inhalation of allergen-derived T cell peptides. Animal experiments have shown that airway hyperresponsiveness (AHR) is CD4+ cell-dependent. It is hypothesised that peptide inhalation produces increases in non-specific AHR and a T cell-dominant bronchial mucosal inflammatory response.

Methods: Bronchoscopy, with bronchial biopsies and bronchoalveolar lavage (BAL), was performed in 24 subjects with cat allergy $6 \mathrm{~h}$ after aerosol inhalation of short overlapping peptides derived from Fel $d \mathrm{l}$, the major cat allergen. Biopsy specimens and BAL fluid were studied using immunohistochemistry and ELISA.

Results: Twelve of the 24 subjects developed an isolated late asthmatic reaction without a preceding early (mast cell/histamine-dependent) reaction characteristic of whole allergen inhalation. These responders had significant between-group differences (responders vs non-responders) in the changes (peptide vs diluent) in AHR $(p=0.007)$ and bronchial mucosal CD3+ $(p=0.005), C D 4+(p=0.006)$ and thymus- and activationregulated chemokine (TARC)+ $(p=0.003)$ but not CD8+ or CD25+ cells or eosinophils, basophils, mast cells and macrophages. The between-group difference for neutrophils was $p=0.05$ but with a non-significant within-group value (peptide vs diluent, responders, $p=0.11$ ). In BAL fluid there was a significant betweengroup difference in TARC $(p=0.02)$ but not in histamine, tryptase, basogranulin, $C 3 a$ or $C 5 a$, leukotrienes $\mathrm{C}_{4} / \mathrm{D}_{4} / \mathrm{E}_{4}$, prostaglandins $\mathrm{D}_{2}$ or $\mathrm{F}_{2 \alpha}$.

Conclusions: Direct activation of allergen-specific airway $T$ cells by peptide inhalation in patients with atopic asthma leads to increased AHR with local increases in CD3+ and CD4+ cells and TARC but no significant changes in eosinophils or basophil/mast cell products. These findings support previous animal experiments which showed a CD4+ dependence for AHR.
\end{abstract}

W e have previously shown that allergen-derived $\mathrm{T}$ cell peptide epitopes, administered either by intradermal injection $^{1}$ or by inhalation, ${ }^{2}$ induce late asthmatic reactions (LAR) in a proportion of individuals with atopic asthma ("responders") but not in others ("non-responders"). These reactions peaked 3-9 $\mathrm{h}$ after peptide inhalation and had a similar time course of onset and resolution to LARs induced by whole allergen extract. They are termed "isolated" late reactions since, unlike whole allergen challenge, there was no early (immediate) asthmatic reaction as the peptides were too short to cross-link IgE on mast cells and did not release histamine from blood basophils. ${ }^{1}$ Thus, our model has the potential to provide information on the $\mathrm{T}$ cell component of allergic airway inflammation independently of initial mast cell activation.

The classic studies of Cockcroft $e t a l^{3}$ and Cartier $e t$ al $l^{4}$ showed that, after inhalation of whole allergen, there were increases in the degree of non-specific airway hyperresponsiveness (AHR) in subjects who develop dual (early and late) asthmatic reactions, but not in those who have only a single early response. Compared with single reactors, dual reactors tend to have raised allergen-specific serum IgE concentrations ${ }^{5}$ which suggests that the degree of mast cell sensitisation may determine the development of the late phase reaction and subsequent AHR. The ability of an anaphylactic anti-IgE to induce late phase skin reactions supports this notion. ${ }^{6}$ On the other hand, several animal studies have shown that AHR can be adoptively transferred by $\mathrm{CD} 4+\mathrm{T}$ cells, ${ }^{7-9}$ and the role of the $\mathrm{T}$ cell in chronic asthma is now firmly established. ${ }^{10}$ For these reasons, we have used our model of peptide-induced isolated
LAR to test the hypothesis that direct activation of allergenspecific airway T cells, independent of the mast cell, produces increased AHR in humans. In this study we show, for the first time, that LARs elicited in atopic subjects by mucosal (inhalational) challenge of allergen-derived $\mathrm{T}$ cell peptides induced increases in non-specific AHR that were associated with a dominant CD3+ and CD4+ bronchial mucosal inflammatory cell response as well as heightened expression of the $\mathrm{T}$ cell chemoattractant thymus- and activation-regulated chemokine (TARC). In contrast, there was no evidence of an involvement of eosinophils, mast cells, basophils or their products in the airways in these peptide-induced LARs (ie, in responders), which supports the view that part of the asthma process has a dominant $\mathrm{T}$ cell component. As a further control, we measured the same variables in age- and sex-matched cat allergic non-responders in whom we found no increases in AHR, CD3+, CD4+ cells or TARC. Thus, in the present study we have measured the concentration of histamine provoking a fall in forced expiratory volume in $1 \mathrm{~s}\left(\mathrm{FEV}_{1}\right)$ of $20 \%$ or more $\left(\mathrm{PC}_{20}\right.$ histamine) as an index of AHR, as well as changes in inflammatory cells, tissue mast cells and soluble mediators in bronchial biopsy specimens and bronchoalveolar lavage (BAL) fluid in both responders and non-responders after the inhala-

Abbreviations: AHR, airway hyperresponsiveness; BAL, bronchoalveolar lavage; CGRP, calcitonin gene-related peptide; $\mathrm{FEV}_{1}$, forced expiratory volume in $1 \mathrm{~s}$; histamine $\mathrm{PC}_{20}$, histamine provocative concentration causing a $20 \%$ fall in $\mathrm{FEV}_{1}$; IL, interleukin; LAR, late asthmatic reaction; $\mathrm{LT}$, leukotriene; MBP, major basic protein; PEFR, peak expiratory flow rate; PG, prostaglandin; TARC, thymus- and activation-regulated chemokine 
tion of either $\mathrm{Fel} d$ l-derived peptides or diluent control. The pharmacological mediators included known bronchoconstricting agents (eg, histamine and eicosanoids), the histaminereleasing complement-derived anaphylotoxins $\mathrm{C} 3 \mathrm{a}$ and $\mathrm{C} 5 \mathrm{a},{ }^{11}$ as well as markers of mast cell degranulation (tryptase and basogranulin). We also measured interleukin (IL)-13 in lavage fluid as this cytokine is known to be associated with increased AHR. ${ }^{12}$ Interleukin-10, a regulatory cytokine, was also assayed to determine whether it was altered in responders compared with non-responders.

\section{METHODS \\ Subjects and study design}

Volunteers with asthma who were allergic to cats were recruited by advertisement and characterised clinically as defined previously. ${ }^{2}$ The study was approved by the Royal Brompton and Harefield NHS Trust ethics committee. All volunteers gave written informed consent. All subjects had a $\mathrm{PC}_{20}$ to histamine of $\leqslant 16 \mathrm{mg} / \mathrm{ml}$ at screening, evidence during the previous 12 months of $>15 \%$ reversibility of the $\mathrm{FEV}_{1}$ or peak expiratory flow rate (PEFR) either spontaneously or after inhaled $\beta_{2}$ agonists, and a clear history of wheezy breathlessness with or without cough on exposure to cats. $\beta_{2}$ agonists were withheld on the study day and inhaled corticosteroids were discontinued 2 months before entering the study. Subjects were excluded if they had received oral corticosteroids in the previous 2 months or Fel $d$ l-derived peptides in the preceding 6 months. Subjects were non-smokers and had no history of current illness or clinically significant abnormalities in routine haematology, biochemistry or urinalysis.

A randomised, placebo-controlled, crossover study design was used. Seven days after screening (visit 1), subjects received either nebulised diluent $(0.9 \%$ saline $)$ or $5 \mu \mathrm{g} \mathrm{Fel} d$ l-derived peptide ( 12 overlapping peptides from chains 1 and 2 of $\mathrm{Fel} d \mathrm{l}$ ). In all instances, subjects were unaware of whether they were inhaling peptides or diluent. The challenge was postponed if the baseline $\mathrm{FEV}_{1}$ fell below $80 \%$ predicted on any study day. To exclude significant worsening of an individual's hyperresponsiveness, the nebulised peptide challenge was administered only if the subject did not exhibit a decrease in $\mathrm{FEV}_{1}$ of $\geqslant 10 \%$ to an initial inhaled control (diluent) challenge. The $\mathrm{FEV}_{1}$ was then recorded at 0, 15, 30 and $60 \mathrm{~min}$ and hourly thereafter for $5 \mathrm{~h}$, at which time bronchoscopy with bronchial biopsies and BAL was performed. Seven days later (visit 3) the histamine $\mathrm{PC}_{20}$ was measured. On visit 4 (minimum of 4 weeks after visit 2) volunteers again inhaled either diluent or peptide (ie, the opposite of what was given on visit 2) and bronchoscopy with biopsies and BAL was again performed. One week later (visit 5) the histamine $\mathrm{PC}_{20}$ was repeated.

Thirty-one subjects entered the study but only 12 developed an isolated LAR $\left(>20 \%\right.$ reduction in $\left.\mathrm{FEV}_{1}\right)$ to peptide. These responders completed both the control and peptide study days. The first 12 subjects who showed no clinical response (nonresponders) to peptide also underwent both challenges and bronchoscopies. The remaining seven non-responders were not investigated since an equal number of subjects in each investigational group (12 responders and 12 non-responders) had been attained.

\section{Peptide synthesis and validation}

Twelve overlapping peptides from chains 1 and 2 of $\mathrm{Fel} d \mathrm{l}$ (chain 1: EICPAVKRDVDLFLTGT, LFLTGTPDEYVEQVAQY, EQVAQYKALPVVLENA, KALPVVLENARILKNCV, RILKNCVDAKMTEEDKE, KMTEEDKENALSLLDK, KENALSVLDKIYTSPL; chain 2: LTKVNATEPERTAMKK, TAMKKIQDCYVENGLI, SRVLDGLVMTTISSSK, ISSSKDCMGEAVQNTV, AVQNTVEDLKLNTLGR) were synthesised and dispensed as described. ${ }^{13}$
These were previously shown not to release histamine from peripheral blood basophils.

\section{Inhalational challenge}

The peptide solution was diluted to $1 \mathrm{ml}$ with $0.9 \%$ saline and delivered through the Pari LC Star nebuliser plus filter and Pari Boy compressor (Pari Medical Ltd, West Byfleet, UK) for $10 \min ^{2}$

\section{Fibreoptic bronchoscopy}

Fibreoptic bronchoscopy with BAL and bronchial biopsies was performed $6 \mathrm{~h}$ after inhalational challenge of either diluent control or Fel $d$ l peptides, as described in detail elsewhere. ${ }^{14}$ BAL fluid and cells and biopsies were also processed as described previously. ${ }^{14}$

\section{Immunohistochemistry}

Cryostat sections $(6 \mu \mathrm{m})$ were freshly cut from biopsy specimens, mounted on $0.1 \%$ poly-L-lysine coated slides and air dried overnight at room temperature. Monoclonal antibody staining was detected by the alkaline phosphatase anti-alkaline phosphatase method as previously described. ${ }^{15}$ Normal human serum $(10 \%)$ was used to prevent non-specific binding of the second and third layer antibodies. A mouse $\operatorname{IgG}_{1}$ myeloma protein was used as a negative control. The monoclonal antibodies used were CD3, CD4, CD8, CD68, neutrophil elastase, human mast cell tryptase (Dako, High Wycombe, UK); CD25 (Becton Dickinson, Cowley, Oxford, UK); major basic protein (MBP) (BMK 13; in-house); TARC (R\&D Systems, Minneapolis, USA) and BBl, a monoclonal antibody which recognises a human basophil granular protein (a gift from Dr A F Walls, University of Southampton, UK). Polyclonal rabbit anti-mouse immunoglobulin and APAAP reagents were purchased from DAKOPATTS (Dako, Ely, UK).

For TARC staining, cryostat sections $(5 \mu \mathrm{m})$ were mounted on Superfrost Plus slides (VWR, Leicester, UK) and air dried overnight at room temperature. TARC was identified using a Vectastain ABC Kit (Vector Laboratories, Peterborough, UK). The reaction was visualised using Fast Red Substrate (Vector Laboratories). The TARC antibody used was raised in the goat (R\&D Systems, Oxford, UK). The numbers of positively stained cells were counted in a zone $250 \mu \mathrm{m}$ deep along the entire length of epithelial basement membrane, as defined by a squared eyepiece graticule. Cell counts were performed in a blinded fashion and expressed as the number of positive cells per $\mathrm{mm}^{2} .^{15}$

\section{Differential BAL cell counts}

Cells counts were performed in a blinded fashion. Unfixed cytospins of BAL cells were stained using Kwik-Diff. The slides were rinsed in phosphate-buffered saline and air dried. In all cases a minimum of 400 nucleated cells were counted per slide.

\section{Histamine measurement}

The histamine content of BAL supernatant and following stimulation of whole blood by BAL was measured by means of a commercially available competitive ELISA kit (Immunotech, Marseilles, France) according to the manufacturer's instructions.

\section{Eicosanoid assays}

BAL supernatants were frozen immediately and stored at $-80^{\circ} \mathrm{C}$ until further analysis. Thawed BAL supernatant $(5 \mathrm{ml})$ was purified and concentrated 10-fold on a C18 column. The recovery of prostaglandins (PGs) and leukotrienes (LTs) was determined by the addition of ${ }^{3} \mathrm{H}_{-}-\mathrm{PGD}_{2} \quad(10000 \mathrm{cpm}$; Amersham Bioscience UK Ltd, Bucks, UK) and ${ }^{3} \mathrm{H}-\mathrm{LTC}_{4}$ 
Table 1 Clinical characteristics of subjects with asthma and cat allergy

\begin{tabular}{lll}
\hline & $\begin{array}{l}\text { Responders } \\
(\mathbf{n}=12)\end{array}$ & $\begin{array}{l}\text { Non-responders } \\
(\mathbf{n}=12)\end{array}$ \\
\hline Ratio M:F & $4: 8$ & $6: 6$ \\
Age (years) & $27(26-34)$ & $28(22.5-28.5)$ \\
Baseline $\mathrm{FEV}_{1}(\% \mathrm{pred})$ & $93.8(87.5-102.7)$ & $92.8(86.1-95.6)$ \\
$\mathrm{PC}_{20}$ histamine (mg/ml) & $3.99(1.67-12.5)$ & $3.99(1.93-4.63)$ \\
Total lgE (IU/ml) & $134(96-248.5)$ & $256.5(197.5-674.5)$ \\
Cat RAST (IU/ml) & $29.2(6.17-43.9)$ & $3.49(1.98-7.07)$ \\
\hline
\end{tabular}

$\mathrm{FEV}_{1}$, forced expiratory volume in $1 \mathrm{~s} ; \mathrm{PC}_{20}$ histamine, concentration of histamine provoking a fall in $\mathrm{FEV}_{1}$ of $20 \%$ or more.

Values shown are numbers or median (interquartile range) ${ }^{*} \mathrm{p}=0.002$

(6000 cpm; NEN Life Science Products, Hounslow, UK), respectively, to each $5 \mathrm{ml}$ aliquot. $\mathrm{LTC}_{4}, \mathrm{LTE}_{4}$ and $11 \beta-\mathrm{PGF}_{2 \alpha}$ in the concentrated samples were measured by enzyme immunoassay (Cayman Chemical Co, Ann Arbor, Michigan, USA). $\mathrm{PGD}_{2}$ in the concentrated samples was converted to $\mathrm{PGD}_{2}$-methoxime $\left(\mathrm{PGD}_{2}-\mathrm{MOX}\right)$, a stable derivative, which was measured by enzyme immunoassay (Cayman Chemical Co). The detection limits of the assays are as follows: $\mathrm{LTC}_{4} 10 \mathrm{pg} / \mathrm{ml}$, $\mathrm{LTE}_{4} 25 \mathrm{pg} / \mathrm{ml}, 11 \beta-\mathrm{PGF}_{2 \alpha} 5.5 \mathrm{pg} / \mathrm{ml}, \mathrm{PGD}_{2}-\mathrm{MOX} 3.6 \mathrm{pg} / \mathrm{ml}$.

The specificity of the $\mathrm{LTC}_{4}$ antibody is $100 \%$ for $\mathrm{LTC}_{4}$ and LTC $_{5}$ and the antibody cross-reacts with LTD $_{4}(46 \%)$ and with $\operatorname{LTE}_{4}(7 \%)$. The specificity of the $\mathrm{LTE}_{4}$ antibody is $100 \%$ for $\mathrm{LTE}_{4}$ and $\mathrm{LTE}_{5}$, with cross-reactivity with $\mathrm{LTC}_{4}(10 \%)$ and $\mathrm{LTD}_{4}(7 \%)$. The specificity of the antibody to $11 \beta-\mathrm{PGF}_{2 \alpha}$ is $100 \%$ for $11 \beta$ $\mathrm{PGF}_{2 \alpha}, 10 \%$ for 2,3 -dinor-11 $\beta-\mathrm{PGF}_{2 \alpha}$ and $<0.01 \%$ for LTs, thromboxane $\mathrm{B}_{2}$ and other PGs. The antibody to $\mathrm{PGD}_{2}-\mathrm{MOX}$ is specific for $\mathrm{PGD}_{2}-\mathrm{MOX}(100 \%)$, with cross-reactivity with $\mathrm{PGD}_{2}$ $(0.2 \%)$ and other PGs $(<0.01 \%)$.

\section{ELISAs for cytokines}

Aliquots of $10 \mathrm{ml}$ BAL supernatant were thawed and immediately concentrated 10 times using Amicon Centriplus kit (Millipore, Billerica, Massachusetts, USA) according to the manufacturer's instructions. The levels of IL-10 and IL-13 in the concentrated BAL supernatants were determined by ELISA (PeliKine Compact kit, CLB, Amsterdam, The Netherlands). The sensitivity of the assays is $1-3 \mathrm{pg} / \mathrm{ml}$ for IL-10 and $0.5-1.5 \mathrm{pg} /$ $\mathrm{ml}$ for IL-13.

\section{Tryptase and basogranulin measurements}

Tryptase measurement was performed using a modification of a previously described ELISA method ${ }^{16}$ that detects both protryptase and the mature forms (with a sensitivity of $0.5 \mathrm{ng} / \mathrm{ml}$ ). Basogranulin assay was performed using a dot blotting procedure with monoclonal antibody $\mathrm{BBl}$ as described previously. ${ }^{17}$ Concentrations were expressed as milliunits $/ \mathrm{ml}$, where 1 unit was taken as the amount of basogranulin in a standard preparation of purified basophils.

\section{$\mathrm{C} 3 \mathrm{a}$ and $\mathrm{C} 5 \mathrm{a}$ assays}

Levels of $\mathrm{C} 3 \mathrm{a} / \mathrm{C} 3 \mathrm{a}$ des-arginine and $\mathrm{C} 5 \mathrm{a} / \mathrm{C} 5 \mathrm{a}$ des-arginine in BAL supernatants were determined by ELISA using BD Biosciences Pharmingen kits (San Diego, USA) according to the manufacturer's instructions. In order to prevent ex vivo complement activation, FUT-175 (Futhan, final concentration $5 \mu \mathrm{g} / \mathrm{ml}$; BD Biosciences, \#552035) was added to each thawed sample. Samples were assayed undiluted, 1:3, 1:6, 1:12 as previously described. ${ }^{11}$ The sensitivities of the assays are $7.3 \mathrm{pg} /$ $\mathrm{ml}$ for $\mathrm{C} 3 \mathrm{a}$ and $0.06 \mathrm{ng} / \mathrm{ml}$ for C5a.

\section{TARC assay}

The TARC level in BAL supernatants was determined by ELISA (R\&D Systems, Abingdon, UK) according to the manufacturer's instructions. The sensitivity of the assay was $7 \mathrm{pg} / \mathrm{ml}$.

\section{BAL fluid assays: protein correction factor}

BAL fluid samples were corrected for variable dilution using protein as an internal reference standard. Protein determination in BAL fluid and concentrated BAL supernatants was performed using bicinchoninic acid protein assay kit (Sigma, St Louis, USA) according to the manufacturer's instructions. The protein concentrations in all samples were normalised to the
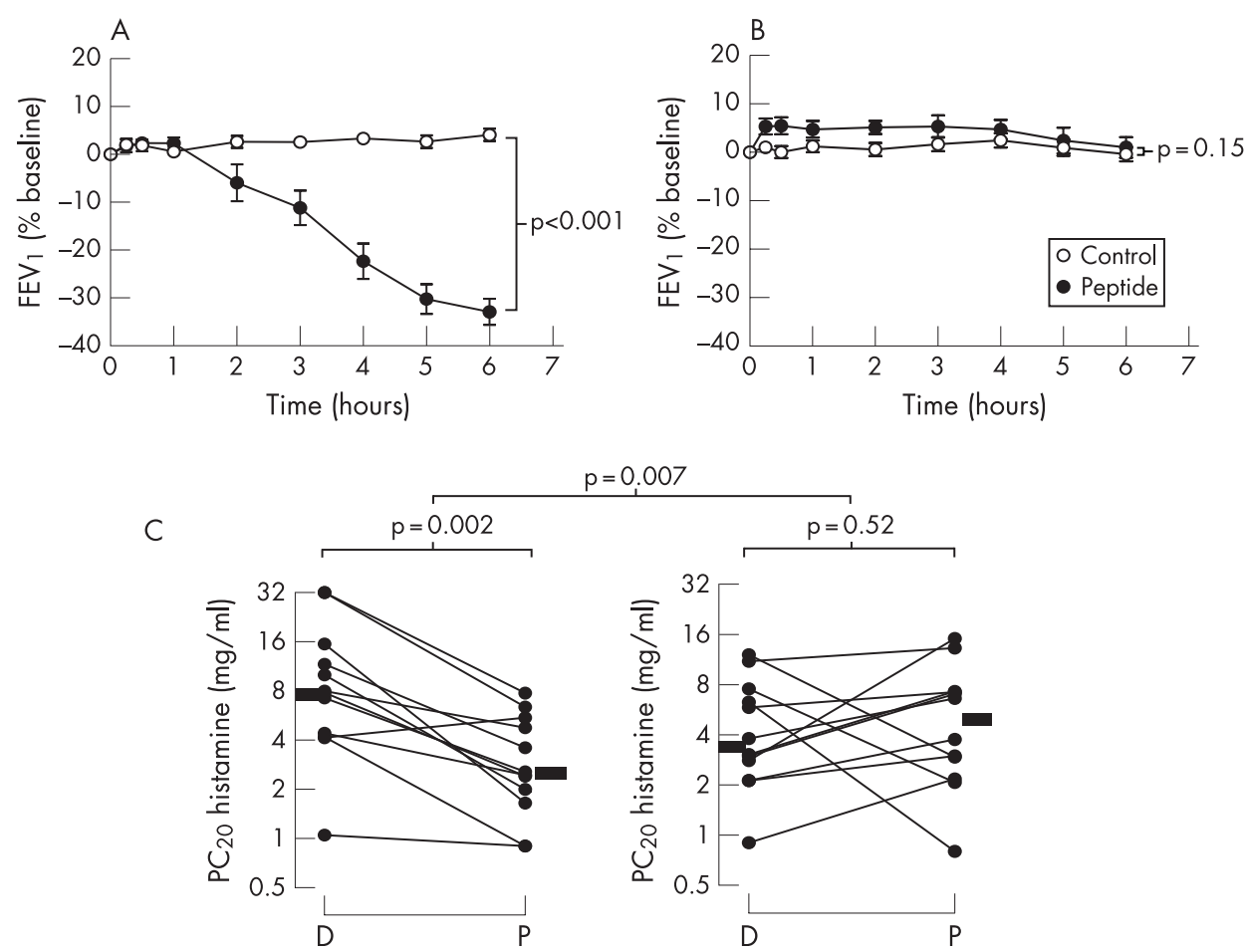

$p=0.007$

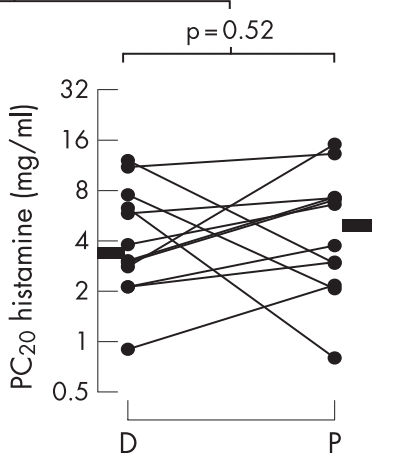

Figure 1 Late asthmatic reactions and airway hyperresponsiveness (AHR) in peptide responders and non-responders. Change in forced expiratory volume in $1 \mathrm{~s}$ ( $\mathrm{FEV}_{1}$ ) after peptide challenge (closed circles) and diluent challenge (open circles) in (A) 12 responders and (B) 12 non-responders. Differences in the area under the curve between the control day and peptide day were analysed by paired $t$ test. (C) Changes in AHR in responders and non-responders 7 days after inhaled challenge. $\mathrm{PC}_{20}$, concentration of histamine provoking a fall in $\mathrm{FEV}_{1}$ of $20 \%$ or more; $\mathrm{D}$, diluent inhalation; $P$, peptide inhalation. Bars represent median values. Within-group comparisons of AHR after diluent and peptide inhalation were performed using two-tailed Wilcoxon signed rank tests. Between-group comparisons of the change from diluent to peptide in responders and non-responders were performed using the non-parametric MannWhitney test. 

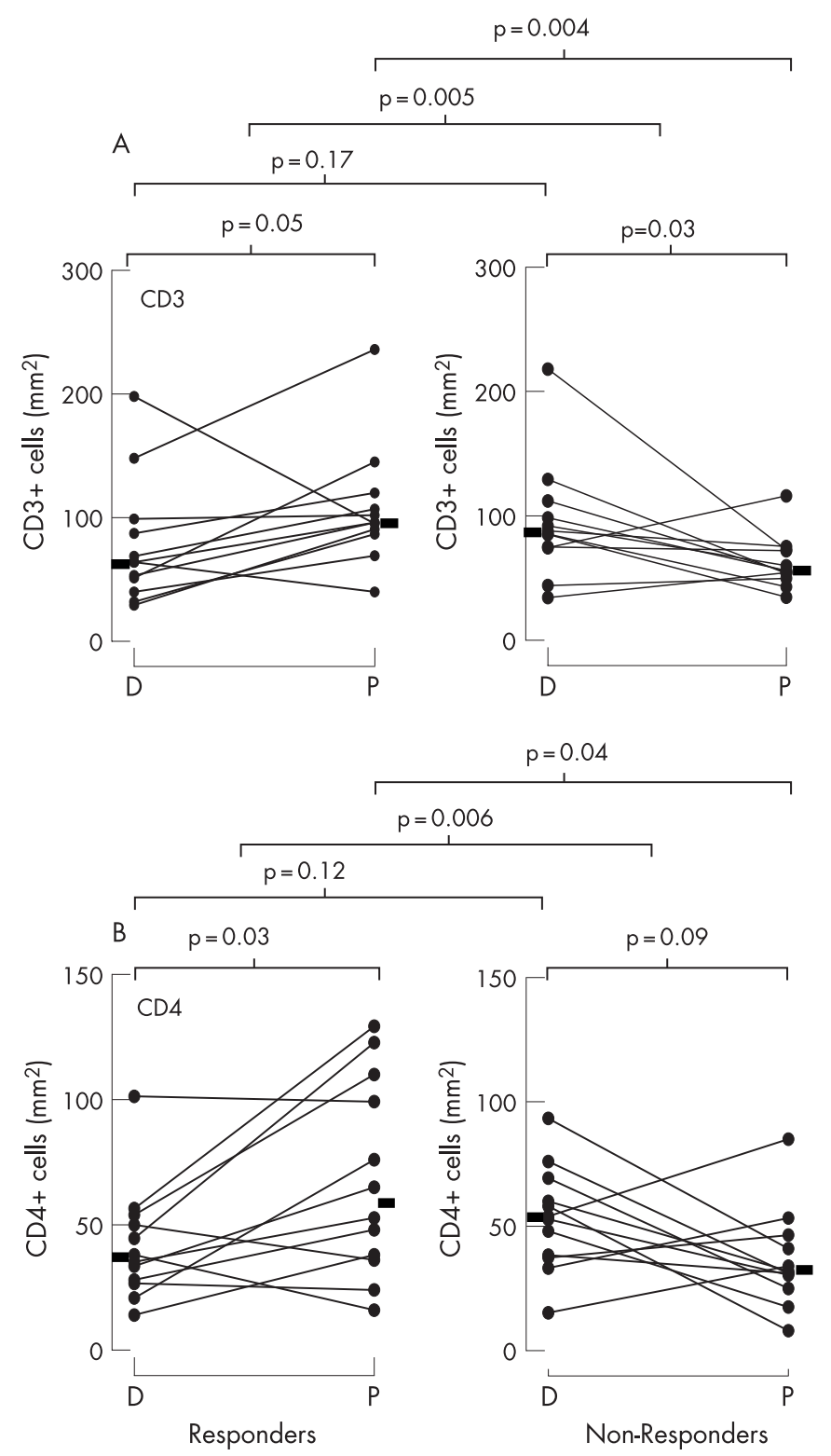

Figure 2 Effect of peptide inhalation on the numbers of (A) CD3+ cells and (B) CD4+ cells in bronchial biopsies from responders and nonresponders. $D$, diluent inhalation; $P$, peptide inhalation. Statistical comparisons of diluent and peptide inhalation (within-group comparisons) were performed using two-tailed Wilcoxon signed rank tests. Betweengroup comparisons of the change from diluent to peptide in responders and non-responders were performed using the non-parametric MannWhitney test. The Mann-Whitney test was also used for unpaired data.

sample with the lowest protein concentration and all values obtained in the assays were corrected accordingly.

\section{Statistical analyses}

Statistical analyses were performed using commercial software packages including GraphPad Prism and p levels of $\leqslant 0.05$ were considered significant. Data from BAL fluid supernatant assays, BAL cytospins, bronchial biopsy immunohistochemistry and in situ hybridisation analyses are expressed as medians with minimum to maximum ranges. Statistical comparisons of diluent and peptide inhalation (within-subject comparisons) were performed using non-parametric two-tailed Wilcoxon signed rank tests. Between-group comparisons of the change from diluent to peptide in responders and non-responders were performed using the non-parametric Mann-Whitney test. The
Mann-Whitney test was also used for unpaired data. Correlations with clinical characteristics were performed using Spearman's rank coefficient of correlation. $\mathrm{FEV}_{1}$ data were summarised over time for each subject for the control (diluent) day and the peptide day. Areas under each curve for the FEV measured over $6 \mathrm{~h}$ were calculated using the trapezoidal rule. Differences in the areas under the curves between the control day and peptide day were analysed by paired $t$ test.

\section{RESULTS}

\section{Effect of peptide challenge on AHR}

At baseline, responders and non-responders were well matched for sex, age, $\mathrm{FEV}_{1}$, histamine $\mathrm{PC}_{20}$ and total serum IgE concentration (table 1). The changes in $\mathrm{FEV}_{1}$ following inhalation of either peptide or diluent in responders and nonresponders are shown in fig $\mathrm{IA}$ and $\mathrm{B}$, respectively. On the peptide day, responders had a mean decrease in $\mathrm{FEV}_{1}$ at $6 \mathrm{~h}$ of approximately $33 \%(\mathrm{p}<0.001)$ while, on the diluent day, there was virtually no change between $\mathrm{FEV}_{1}$ at baseline and after $6 \mathrm{~h}$ in responders. No changes in $\mathrm{FEV}_{1}$ occurred on diluent or peptide days in non-responders. There was a highly significant increase in cat-specific serum IgE in responders compared with non-responders despite a non-significantly lower concentration of total $\operatorname{IgE}(\mathrm{p}=0.002$, table 1$)$. Changes in AHR are shown in fig $\mathrm{IC}$. There was a significant decrease in the histamine $\mathrm{PC}_{20}$ in responders ( $p=0.002$ diluent vs peptide) which was not observed in non-responders $(\mathrm{p}=0.52$ diluent vs peptide). The between-group difference in the changes was $p=0.007$. On entering the study, all subjects had mild asthma with a history of cat-induced wheeze. At screening they all had a $\mathrm{PC}_{20}$ histamine of $<16 \mathrm{mg} / \mathrm{ml}$. However, in two of the subjects the values changed to $>16 \mathrm{mg} / \mathrm{ml}$ during the course of the study (fig 1C).

\section{Association of isolated LARs with recruitment of CD3+CD4+ T cells}

In responders there were significant increases (diluent vs peptide) in the numbers of CD3+ $(p=0.05)$ and CD4+ cells $(\mathrm{p}=0.03$; fig 2 and table 2$)$, with decreases in non-responders $(p=0.03$ for $\mathrm{CD} 3+$ and $p=0.09$ for CD4+ cells, table 2$)$. The between-group differences in the changes were $p=0.005$ for CD $3+$ cells and $p=0.006$ for CD4+ cells (fig 2 and table 2). Using a non-paired test, the numbers of CD3+ and CD4+ cells were also significantly higher in responders than in nonresponders following peptide challenge $(\mathrm{p}=0.004$ and $\mathrm{p}=0.04$, respectively), but not following inhaled diluent (fig 2). A representative photomicrograph of $\mathrm{CD} 4+$ immunostaining in bronchial biopsy specimens from responders and non-responders is shown in fig 3. In responders (diluent vs peptide) there was only a trend for increases in MBP+ eosinophils $(p=0.07$, table 2). Although there was no significant within-group increase in elastase+ neutrophils $(p=0.11)$ in responders (diluent vs peptide), the between-group value just reached significance $(p=0.05)$. There were no significant changes in CD8+ and CD25+ cells or in BBl+ basophils or tryptase+ mast cells (table 2).

Eosinophil and neutrophil counts in BAL fluid showed no significant change in either responders or non-responders (diluent vs peptide). The $\mathrm{p}$ values for between-group differences were 0.44 and 0.37 for eosinophils and neutrophils, respectively (data not shown).

\section{Association of isolated LARs with increased expression of the Th2 chemokine TARC}

There was a significant increase in the concentration of TARC in BAL fluid (diluent vs peptide) in responders $(p=0.004)$ but not in non-responders $(\mathrm{p}=0.97)$ with a between-group difference 
Table 2 Effect of peptide inhalation on lymphocyte, macrophage, eosinophil, neutrophil, basophil and mast cell counts in bronchial biopsy specimens from responders and non-responders

\begin{tabular}{|c|c|c|c|c|c|c|c|}
\hline \multirow[b]{2}{*}{ Cell markers } & \multicolumn{3}{|l|}{ Responders (R) } & \multicolumn{3}{|l|}{ Non-responders (NR) } & \multirow{2}{*}{$\begin{array}{l}\text { p Value } \\
\text { (R vs NR) }\end{array}$} \\
\hline & Diluent & Peptide & p Value & Diluent & Peptide & p Value & \\
\hline $\mathrm{CD} 3$ & $64(29.3-198.0)$ & $96(40.0-236.0)$ & 0.05 & $86.7(34.4-218)$ & $55.5(34.7-116)$ & 0.03 & 0.005 \\
\hline $\mathrm{CD} 4$ & $36.6(14.0-101.3)$ & $58.9(16.0-129.3)$ & 0.03 & $53.4(15.2-93.3)$ & $31.6(8.0-85.0)$ & 0.09 & 0.006 \\
\hline CD8 & $34.2(18.9-72.0)$ & $38.7(18.7-72.0)$ & 0.85 & $47.2(10.0-87.0)$ & $38.2(13.3-69.3)$ & 0.23 & 0.54 \\
\hline $\mathrm{CD} 25$ & $38.7(14.7-96.0)$ & $46.7(12.0-88.0)$ & 0.38 & $41.3(11.2-84.0)$ & $40.7(12.0-84.0)$ & 1.03 & 0.6 \\
\hline CD68+ macrophages & $28.1(15.3-62.0)$ & $28.1(9.8-67.0)$ & 0.85 & $35(16.0-84.0)$ & $34.6(5.6-66.7)$ & 0.68 & 0.58 \\
\hline $\mathrm{MBP}+$ eosinophils & $29(18.4-61.3)$ & $40.2(18.4-160.0)$ & 0.07 & $33.3(14.0-52.0)$ & $20.3(12.8-81.6)$ & 0.79 & 0.09 \\
\hline Elastase+ neutrophils & $44.4(20.5-98.0)$ & $60.7(32.0-108.0)$ & 0.11 & $47.3(22.4-72.0)$ & $37.7(28.7-68.0)$ & 0.38 & 0.05 \\
\hline BB1+ basophils & $53(18.5-94.0)$ & $45.1(18.7-128.0)$ & 0.73 & $39.3(20.6-100.0)$ & $59.8(20.0-94.0)$ & 0.2 & 0.31 \\
\hline Tryptase + mast cells & $45.8(22.0-72.0)$ & $49(22.7-84.0)$ & 0.73 & $41.6(22.5-76.0)$ & $41(20.0-66.0)$ & 0.62 & 0.75 \\
\hline
\end{tabular}

The results are expressed as the number of positive cells (median and range) per $\mathrm{mm}^{2}$ beneath the basement membrane. Statistical comparisons of diluent and peptide inhalation (within-group comparisons) were performed using two-tailed Wilcoxon signed rank tests. Between-group comparisons of the change from diluent to peptide in responders and nonresponders were performed using the non-parametric Mann-Whitney test.

of $\mathrm{p}=0.02$ (fig $4 \mathrm{~A}$ ). However, as shown by the non-paired test, the concentrations of TARC were significantly higher in nonresponders than in responders following diluent $(p=0.03)$ but not following peptide challenge (fig 4A).

The results for TARC+ immunoreactive cells in bronchial biopsy specimens are shown in fig 4B. There was a significant increase in TARC+ cells (diluent vs peptide) in responders $(p=0.005)$ but not in non-responders $(p=0.68)$, with a between-group difference of $p=0.003$. However, unlike BAL fluid, there was no significant difference in TARC+ cells after diluent challenge but a significant increase after peptide $(p=0.02$, fig $4 B)$. TARC + cells included eosinophils, neutrophils and mononuclear cells. There was also increased positive TARC staining in epithelial cells in responders but this was not formally quantified. There was a positive correlation between the magnitude of the LAR (expressed as area under the curve) and the delta changes (diluent vs peptide) in the 12 responders for TARC+ cells in biopsy specimens $(\mathrm{r}=0.59, \mathrm{p}<0.05)$. A representative photomicrograph of TARC+ immunostaining in bronchial biopsy specimens from responders and non-responders is shown in fig 3.

\section{Effect on BAL fluid levels of pharmacological mediators, IL- 13 and IL- 10}

The concentrations of various mast cell- and basophil-associated pharmacological mediators in BAL fluid are shown in table 3. There were no significant differences (responders vs non-responders, diluent vs peptide) in histamine, tryptase,
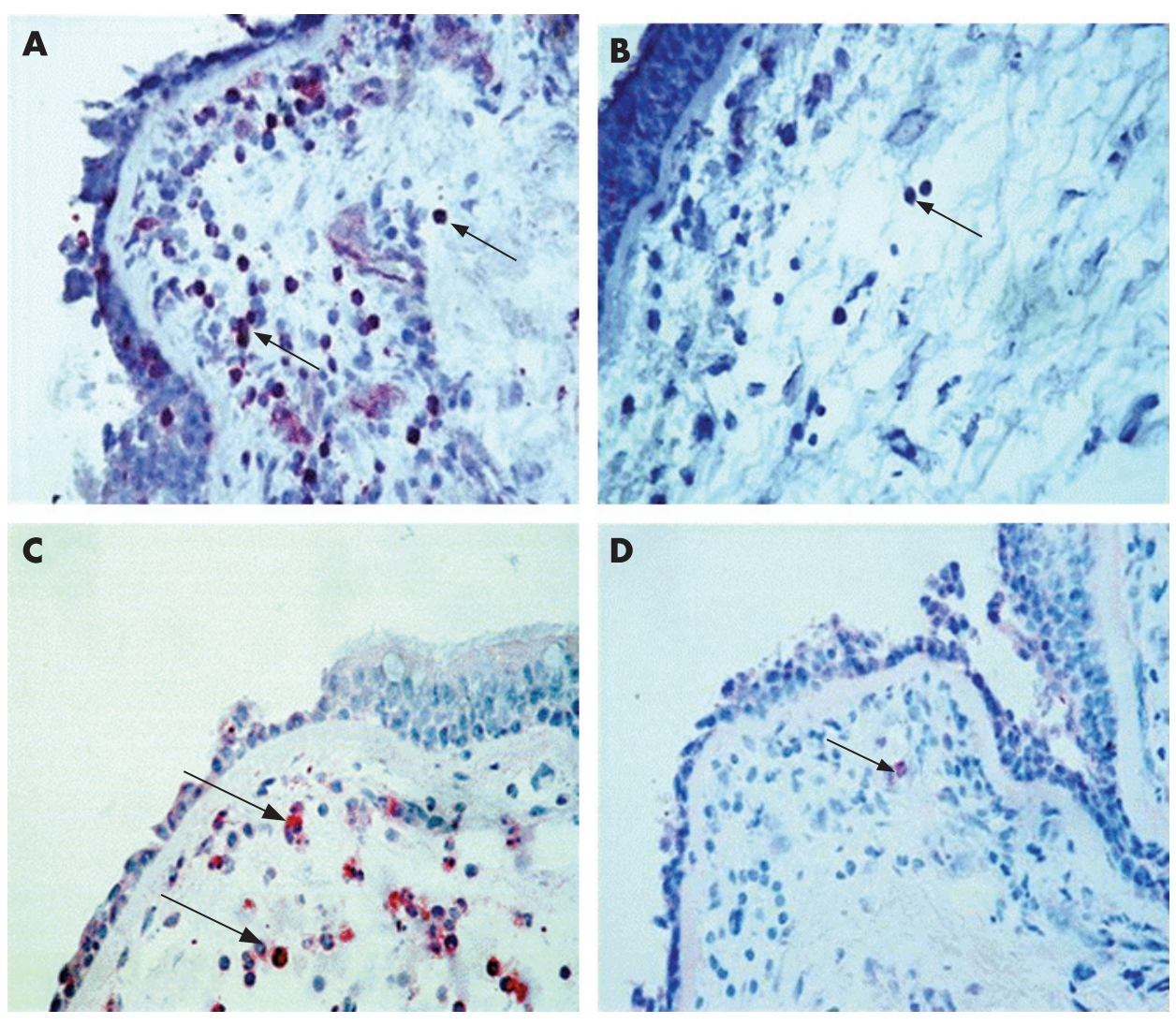

Figure 3 Photomicrographs of CD4+ cells and thymus- and activation-regulated chemokine (TARC)+ cells in bronchial biopsy specimens from responders and non-responders. CD4+ cells after peptide challenge in (A) a responder and (B) a non-responder. TARC+ cells after peptide challenge in (C) a responder and (D) a non-responder. Arrows show examples of immunopositive cells. 


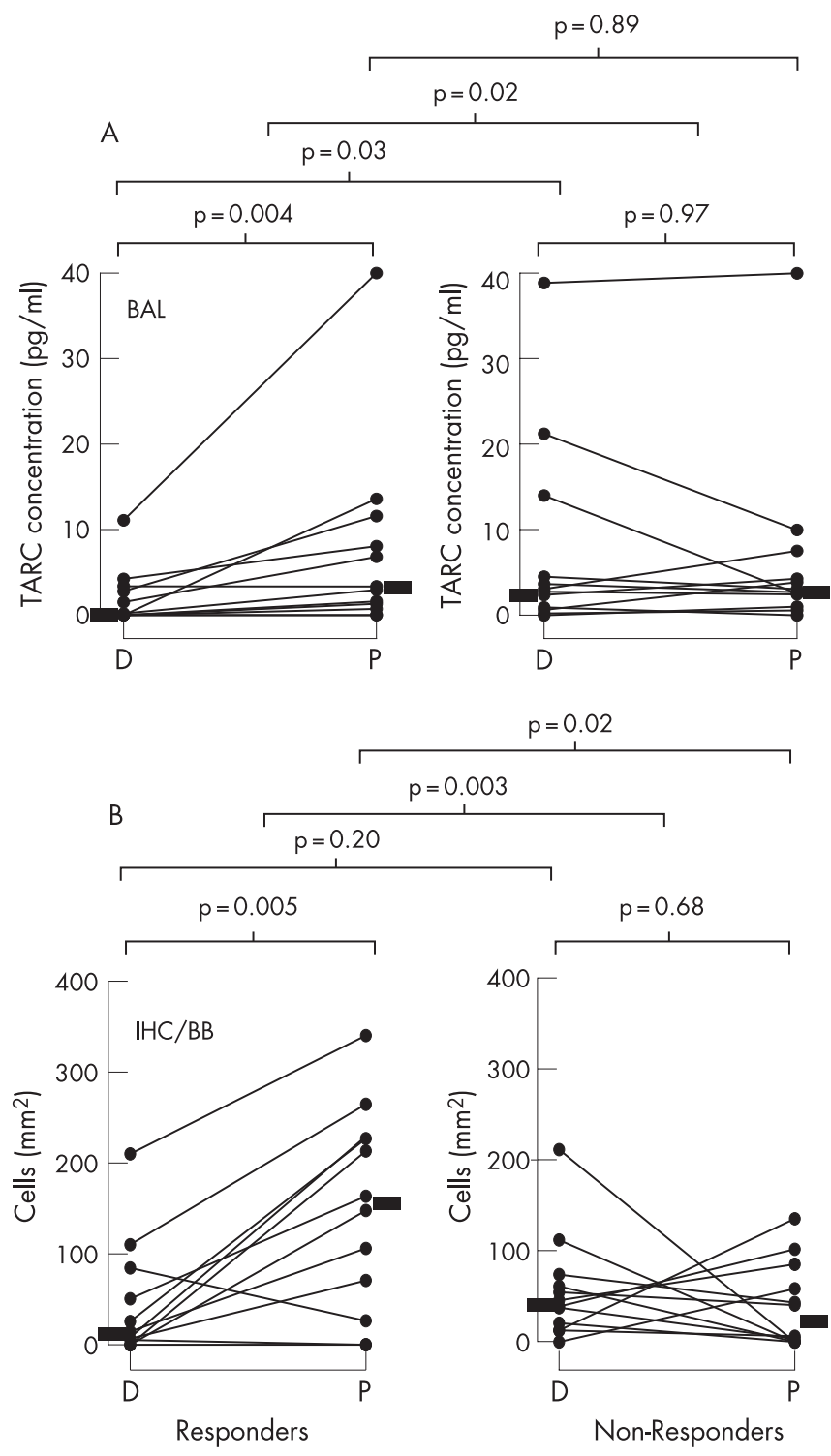

Figure 4 Effect of peptide inhalation on (A) the concentration of thymusand activation-regulated chemokine (TARC) in bronchoalveolar lavage fluid and (B) the numbers of TARC+ protein+ cells in bronchial biopsy specimens from responders and non-responders. $D$, diluent inhalation; $P$, peptide inhalation. Statistical analysis was performed as described in fig 2. basogranulin, $\quad \mathrm{LTC}_{4} / \mathrm{LTD}_{4} / \mathrm{LTE}_{4} \mathrm{PGD}_{2}, \mathrm{PGF}_{2 \alpha}$ and fragments cleaved from C3 (C3a). C5a was not detectable in any sample. There were also no significant increases (diluent vs peptide) in the concentrations of IL-13 or IL-10 in BAL fluid from responders or non-responders (data not shown).

\section{DISCUSSION}

The important novel observation of this study is that, in subjects with asthma, selective activation of allergen-specific $\mathrm{T}$ cells by inhalation of allergen-derived peptides is sufficient to induce increases in non-specific AHR (a cardinal feature of asthma) which, in turn, is accompanied by a predominantly $\mathrm{T}$ cell bronchial mucosal inflammatory response. Thus, in responders but not in non-responders, inhalation of peptides produced increased AHR (measured 7 days after peptide provocation) as well as a LAR (which peaked at $6 \mathrm{~h}$ after challenge) as previously described..$^{213}$

The increased numbers of CD3+, CD4+ and TARC+ cells in biopsy specimens supports the view that increased AHR is linked to $\mathrm{T}$ cell activation and are in keeping with previous animal studies. For example, adoptive transfer experiments in Brown Norway rats have shown that AHR can be transferred by allergen-specific CD4+ T cells. ${ }^{89}$ Moreover, in mice, using a combination of anti-T cell monoclonal antibody, $\mathrm{T}$ cell transfer and bone marrow transplantation, it was shown that $\mathrm{T}$ cells enhanced genetically determined AHR. ${ }^{7}$ Furthermore, depletion of murine CD4+ T lymphocytes prevented antigen-induced AHR and pulmonary eosinophilia. ${ }^{18} 19$

In a previous study ${ }^{14}$ we examined bronchial biopsies and BAL fluid from responders and non-responders $6 \mathrm{~h}$ after an intradermal injection of allergen-derived peptides (ie, when airway narrowing was maximal). Surprisingly, we found no changes (diluent vs peptide challenge) in the numbers of eosinophils, neutrophils, basophils, mast cells, T cells and T cell subsets, macrophages, Th2 cytokines, histamine, histaminereleasing factors or eicosanoids. However, as the challenge route was systemic, $\mathrm{T}$ cell activation may have occurred in perivascular tissue distal to bronchoscopic sampling. In the present study peptides were delivered via the inhaled route using a method previously reported, ${ }^{2}$ so we anticipated that, with direct airway challenge, we were more likely to observe mucosal infiltration of inflammatory cells and changes in concentrations of pharmacological mediators. In fact, with the exception of increases in airway T cells, our findings using the inhaled route were very similar to those observed with LARs provoked by intradermal challenge. ${ }^{14}$ For example, no increases

Table 3 Effect of peptide inhalation on the concentrations of mast cell- and basophil-associated pharmacological mediators in bronchoalveolar lavage (BAL) fluid from responders and non-responders

\begin{tabular}{|c|c|c|c|c|c|c|c|}
\hline \multirow[b]{2}{*}{ Mediators } & \multicolumn{3}{|l|}{ Responders (R) } & \multicolumn{3}{|c|}{ Non-responders (NR) } & \multirow{2}{*}{$\begin{array}{l}\text { p Value } \\
\text { (R vs NR }\end{array}$} \\
\hline & Diluent & Peptide & p Value & Diluent & Peptide & p Value & \\
\hline Histamine & $4.8(2.0-9.9)$ & $7.9(2.7-17.3)$ & 0.02 & $3.8(0.7-8.1)$ & $5.5(1.7-8.7)$ & 0.18 & 0.24 \\
\hline Tryptase & $0.6(0-2.3)$ & $0.6(0-6.3)$ & 0.76 & $0(0-0.6)$ & $0.2(0-1.5)$ & 0.08 & 0.98 \\
\hline Basogranulin & $39.9(0-995.0)$ & $49.3(2.7-160.1)$ & 0.52 & $47.0(8.2-194.4)$ & $29.3(3.2-117.0)$ & 0.06 & 0.13 \\
\hline $\mathrm{C} 3 \mathrm{a}^{*}$ & $5.4(4.0-8.7)$ & $5.9(3.2-9.0)$ & 0.76 & $8.8(5.4-11.1)$ & $7.5(4.6-9.3)$ & 0.31 & 0.21 \\
\hline $\mathrm{LTC}_{4} / \mathrm{D}_{4}$ & $5.5(2.2-17.7)$ & $8.2(1.4-19.5)$ & 0.73 & $3.2(1.1-12.1)$ & $3.7(1.2-26.0)$ & 0.09 & 0.51 \\
\hline $\mathrm{LTE}_{4}$ & $6.0(1.2-34.6)$ & $6.7(2.5-27.8)$ & 0.38 & $7.0(2.3-14.1)$ & $5.8(2.7-25.6)$ & 0.79 & 0.62 \\
\hline $\mathrm{PGD}_{2}$ & $0.95(0-8.2)$ & $2.7(0-9.8)$ & 0.92 & $0.9(0-9.5)$ & $2.9(0-21.2)$ & 0.09 & 0.16 \\
\hline $\mathrm{PGF}_{2 \alpha}$ & $2.1(0.7-3.4)$ & $1.6(0.6-4.6)$ & 0.73 & $1.4(0.6-4.0)$ & $1.4(0.49-4.1)$ & 0.97 & 0.93 \\
\hline
\end{tabular}

LT, leukotriene; PG, prostaglandin

Values are expressed as median (range).

Statistical comparisons of diluent and peptide inhalation (within-group comparisons) were performed using two-tailed Wilcoxon signed tank tests. Between-group comparisons of the change from diluent to peptide in responders and non-responders were performed using the non-parametric Mann-Whitney test. All values are expressed as $\mathrm{pg} / \mathrm{ml}$ of BAL fluid with the exception of histamine, C3a and tryptase $(\mathrm{ng} / \mathrm{ml})$ and basogranulin $(\mathrm{mU} / \mathrm{ml})$. ${ }^{*} \mathrm{C} 5 \mathrm{a}$ was not detected in any sample. 
were observed in the BAL fluid concentrations of tryptase, basogranulin, $\mathrm{C} 3 \mathrm{a}, \mathrm{C} 5 \mathrm{a}, \mathrm{LTC}_{4} / \mathrm{D}_{4} / \mathrm{E}_{4}, \mathrm{PGD}_{2}$ or $\mathrm{PGF}_{2 \alpha}$ between diluent and peptide in either responders or non-responders. With the exception of basogranulin, these mediators have all been shown to be increased in BAL fluid following whole allergen challenge.

Although there was an increase in neutrophils and a trend for an increase in eosinophils, there were no significant changes in the numbers of basophils or macrophages. This is in contrast to changes induced in the airways after challenge with whole allergen. For example, in our previous study in which we measured cells and mediators in the airways $6 \mathrm{~h}$ after whole allergen challenge, there were increases in bronchial eosinophils, neutrophils, T cells, histamine and $\mathrm{LTC}_{4}$ in dual but not single early responders. ${ }^{20}$ Others have also observed whole allergen-induced airway eosinophilia in subjects with mild asthma at the $6 \mathrm{~h}$ time point ${ }^{21}{ }^{22}$ Taken together, these studies support the view that eosinophil infiltration is more likely to be secondary to mast cell rather than $\mathrm{T}$ cell activation, and therefore might not occur following $\mathrm{T}$ cell peptide inhalation since there is a lack of IgE cross-linking on mast cells. Furthermore, the role of the eosinophil in allergen-induced late reactions has been cast in doubt since depletion of this cell with anti-IL-5 had no effect on either late phase asthmatic ${ }^{23}$ or skin reactions. ${ }^{24}$ Nevertheless, we cannot completely exclude the role of eosinophils and neutrophils in peptide-induced LARs, especially as the study population was small. However, taken together with our previous biopsy and lavage study, our data would suggest that they are not crucial cells in the pathogenesis of the peptide-induced late phase reaction.

An unexpected finding was that the concentrations of TARC were significantly higher in non-responders than in responders following diluent challenge (fig 4A) as shown by a non-paired test $(p=0.03)$. In fact, this was in large part due to two subjects who had a particularly high response to diluent challenge. The fact that the more meaningful paired within-group and between-group data showed significance with BAL fluid and that there was a very clear TARC immunoreactive positive cell response at the level of the bronchial mucosa (fig 4B) suggests that changes in this Th2 chemokine are central and relevant in our model of asthma.

A further novel finding was that at baseline (ie, before challenge) the responders had significantly raised serum catspecific IgE compared with non-responders. It has previously been shown that dual responders (those who develop early and late asthmatic reactions and subsequent increased AHR after whole allergen challenge) tended to have raised allergenspecific IgE compared with single early responders. ${ }^{5}$ This observation may help to predict why some, but not all, catsensitive individuals develop a LAR after the Fel $d$ l peptide challenge. Thus, raised levels of allergen-specific serum IgE may reflect high IgE density on airway dendritic cells and/or the frequency of allergen-specific $\mathrm{T}$ cells in the airway mucosa. Further experiments will be required to test these hypotheses. It should be emphasised that the present study supports the view that increased AHR occurs after a LAR irrespective of whether this is induced by whole allergen (and therefore preceded by a mast cell-dependent early response) or is an isolated peptideinduced LAR as in the present study. In both situations (whole allergen or peptide challenge) the subjects who develop a LAR have raised serum levels of allergen-specific IgE. Thus, T cell activation rather than mast cell activation may be more crucial for the development of increased AHR as previously observed in animal studies. ${ }^{7-9}$

In summary, the following mechanism is proposed. Inhaled $\mathrm{T}$ cell peptide epitopes bind to MHC class II molecules expressed in the airways leading to activation of peptide-specific resident effector memory T cells. Activation of these cells enhances local production of TARC from antigen-presenting cells, structural cells and accessory cells. Increased TARC expression leads to recruitment and activation of CD3+/CD4+ T cells, production of inflammatory cytokines (although this has yet to be demonstrated) and, ultimately, increased AHR. Our inability to demonstrate cells mRNA+ for Th2 cytokines in $6 \mathrm{~h}$ biopsy specimens may have been related to the small numbers of IL-4, IL-5 and IL-13 positive cells at this time point (as opposed to $24 \mathrm{~h}$ where previously we have found increases after whole allergen challenge ${ }^{25}$ ). The mechanism of the late-phase reaction itself remains uncertain but, in a recent report, ${ }^{26}$ we showed markedly raised expression of calcitonin gene-related peptide (CGRP) in epithelial cells, infiltrating CD3+/CD4+ cells and smooth muscle in responders (but not non-responders) after peptide challenge. Since CGRP is a potent vasodilator, this raises the possibility that airway wall oedema may be an important component of peptide-induced late reactions. In any case, the present findings support the view that $\mathrm{T}$ cell activation alone is capable of triggering these events, observations which may be of importance to unravelling events in chronic severe asthma where the role of the T cell is now well established.

\section{ACKNOWLEDGEMENTS}

The authors acknowledge the valuable assistance of the following: $\mathrm{Mr}$ Farid Benyahia and Ms Julia Barkans (immunohistochemistry work, TARC assay); Dr Sun Ying (immunohistochemistry work); Dr Cecilia P C Soh and Professor Tak H Lee (measurements of eicosanoids in BAL fluid); Dr Andrew Walls and Dr Aki Mochizuki (measurements of tryptase and basogranulin in BAL fluid); Dr Alison Humbles (measurements of C3a and C5a in BAL fluid).

\section{Authors' affiliations \\ F Runa Ali, A Barry Kay, Mark Larché, Departments of Allergy and Clinical Immunology and Leukocyte Biology, MRC and Asthma UK Centre in Allergic Mechanisms of Asthma, NHLI Division, Imperial College, London, UK}

This study was supported by the Medical Research Council (UK) and Asthma UK.

Competing interests: $A B K$ and ML have shares in Circassia Holdings.

\section{REFERENCES}

1 Haselden BM, Kay AB, Larché M. Immunoglobulin E-independent major histocompatibility complex-restricted T cell peptide epitope-induced late asthmatic reactions. J Exp Med 1999;189:1885-94.

2 Ali FR, Oldfield WL, Higashi N, et al. Late asthmatic reactions induced by inhalation of allergen-derived T cell peptides. Am J Respir Crit Care Med 2004; 169:20-6.

3 Cockcroft DW, Ruffin RE, Dolovich J, et al. Allergen-induced increase in nonallergic bronchial reactivity. Clin Allergy 1977;7:503-13.

4 Cartier A, Thomson NC, Frith PA, Roberts R, et al. Allergen-induced increase in bronchial responsiveness to histamine: relationship to the late asthmatic response and change in airway caliber. J Allergy Clin Immunol 1982;70:170-7.

5 Cockcroft DW, Ruffin RE, Frith PA, et al. Determinants of allergen-induced asthma: dose of allergen, circulating lgE antibody concentration, and bronchial responsiveness to inhaled histamine. Am Rev Respir Dis 1979;120:1053-8.

6 Solley GO, Gleich GJ, Jordon RE, et al. The late phase of the immediate wheal and flare skin reaction. Its dependence upon IgE antibodies. J Clin Invest 1976;58:408-20.

7 De Sanctis GT, Itoh A, Green FH, et al. T-lymphocytes regulate genetically determined airway hyperreactivity in mice. Nat Med 1977;3:460-2.

8 Haczku A, Macary P, Huang TJ, et al. Adoptive transfer of allergen-specific $\mathrm{CD} 4+\mathrm{T}$ cells induces airway inflammation and hyperresponsiveness in brownNorway rats. Immunology 1977;91:176-85.

9 Mishima H, Hojo M, Watanabe A, et al. CD4+ T cells can induce airway hyperresponsiveness to allergen challenge in the brown Norway rat. Am J Respir Crit Care Med 1998;158:1863-70.

10 Larché M, Robinson DS, Kay AB. The role of T lymphocytes in the pathogenesis of asthma. J Allergy Clin Immunol 2003;111:450-61.

11 Humbles AA, Lu B, Nilsson CA, Lilly C, et al. A role for the C3a anaphylatoxin receptor in the effector phase of asthma. Nature 2000;406:998-1001. 
12 Kuperman DA, Huang X, Koth LL, et al. Direct effects of interleukin-13 on epithelial cells cause airway hyperreactivity and mucus overproduction in asthma. Nat Med 2002;8:885-9.

13 Oldfield WL, Kay AB, Larché M. Allergen-derived T cell peptide-induced late asthmatic reactions precede the induction of antigen-specific hyporesponsiveness in atopic allergic asthmatic subjects. J Immunol 2001;167:1734-9.

14 Haselden BM, Larché $M$, Meng $Q$, et al. Late asthmatic reactions provoked by intradermal injection of T-cell peptide epitopes are not associated with bronchial mucosal infiltration of eosinophils or $\mathrm{T}(\mathrm{H}) 2$-type cells or with elevated concentrations of histamine or eicosanoids in bronchoalveolar fluid. J Allergy Clin Immunol 2001; 108:394-401

15 Ying S, Humbert M, Barkans J, et al. Expression of IL-4 and IL-5 mRNA and protein product by CD4+ and CD8+ T cells, eosinophils, and mast cells in bronchial biopsies obtained from atopic and nonatopic (intrinsic) asthmatics. $J$ Immunol 1997; 158:3539-44.

16 Buckley MG, VariendS, Walls AF. Elevated serum concentrations of betatryptase, but not alpha-tryptase, in sudden infant death syndrome (SIDS). An investigation of anaphylactic mechanisms. Clin Exp Allergy 2001;31:1696-704.

17 Mochizuki A, McEuen AR, Buckley MG, et al. The release of basogranulin in response to $\mathrm{lg} \mathrm{E}$-dependent and $\mathrm{lg} \mathrm{E}$-independent stimuli: validity of basogranulin measurement as an indicator of basophil activation. J Allergy Clin Immunol 2003;112:102-8.

18 Gavett SH, Chen X, Finkelman F, et al. Depletion of murine CD4+ T lymphocytes prevents antigen-induced airway hyperreactivity and pulmonary eosinophilia. Am J Respir Cell Mol Biol 1994;10:587-93.
19 Hogan SP, Matthaei KI, Young JM, et al. A novel T cell-regulated mechanism modulating allergen-induced airways hyperreactivity in $\mathrm{BALB} / \mathrm{c}$ mice independently of IL-4 and IL-5. J Immunol 1998;161:1501-9.

20 Diaz P, Gonzalez MC, Galleguillos FR, et al. Leukocytes and mediators in bronchoalveolar lavage during allergen-induced late-phase asthmatic reactions. Am Rev Respir Dis 1989;139:1383-9.

21 Aalbers R, Kauffman HF, Vrugt B, et al. Bronchial lavage and bronchoalveolar lavage in allergen-induced single early and dual asthmatic responders. Am Rev Respir Dis 1993;147:76-81.

22 Gratziou C, Carroll M, Montefort S, et al. Inflammatory and T-cell profile of asthmatic airways 6 hours after local allergen provocation. Am J Respir Crit Care Med 1996;153:515-20.

23 Leckie MJ, ten Brinke A, Khan J, et al. Effects of an interleukin-5 blocking monoclonal antibody on eosinophils, airway hyper-responsiveness, and the late asthmatic response. Lancet 2000;356:2144-8.

24 Phipps S, Flood-Page P, Menzies-Gow A, et al. Intravenous anti-IL-5 monoclonal antibody reduces eosinophils and tenascin deposition in allergen-challenged human atopic skin. J Invest Dermatol 2004;122:1406-12.

25 Bentley AM, Meng Q, Robinson DS, et al. Increases in activated T lymphocytes, eosinophils, and cytokine mRNA expression for interleukin-5 and granulocyte/ macrophage colony-stimulating factor in bronchial biopsies after allergen inhalation challenge in atopic asthmatics. Am J Respir Cell Mol Biol 1993;8:35-42.

26 Kay AB, Ali FR, Heaney LG, et al. Airway expression of calcitonin gene-related peptide in T cell peptide-induced late asthmatic reactions in atopics. Allergy 2007;62:495-503.

\section{LUNG ALERT}

\section{What factors are predictive of survival in patients with non-small-cell lung cancer treated with gefitinib?}

$\Delta$ Satouchi M, Negoro S, Funada Y, et al. Predictive factors associated with prolonged survival in patients with advanced nonsmall-cell lung cancer (NSCLC) treated with gefitinib. Br J Cancer 2007;96:1191-6.

T his study identified factors associated with prognostic benefit from gefitinib chemotherapy. Japanese patients who had received gefitinib monotherapy between 2002 and 2005 at the Hyogo Medical Centre for Adults in Japan $(n=221)$ were included in the study. Their clinical parameters were retrospectively examined for potential predictive factors of survival.

Median survival time was better in females, 13.3 vs 6.8 months $(=0.036)$; patients with adenocarcinoma, 9.3 vs 3.6 months $(p=0.137)$; never smokers, 14.5 vs 6.5 months $(p<0.001)$; those with favourable performance status, 11.1 vs 2.1 months $(\mathrm{p}<0.001)$; and patients with epidermal growth factor receptor (EGFR) mutation, $24.9 \mathrm{vs} 7.4$ months $(\mathrm{p}<0.001)$. The lower the smoking exposure (Brinkman Index: cigarettes per day $\times$ years smoked) the longer the mean survival time $(\mathrm{p}<0.001)$. Multivariate analysis showed that positive EGFR mutation status and performance status $0-1$ were independent predictors of a favourable prognosis.

Prognosis was significantly different according to EGFR mutation status (with the same smoking status), but not according to smoking status (with the same EGFR mutation status). The authors suggest that although smoking is not a direct predictor of prognosis, it may be useful as a surrogate marker for EGFR mutation status. They concluded that EGFR mutation status is the most important independent predictor of survival benefit with gefitinib treatment.

Kirsten Archer

Specialist Registrar, Basildon Hospital, UK; kirstenarcher@doctors.net.uk 